\title{
5 Vulnerabilities and resilience of local women towards climate change in the Indus basin
}

\author{
Saqib Shakeel Abbasi, Muhammad Zubair \\ Anwar, Nusrat Habib, and Qaiser Khan
}

\section{Introduction}

Pakistan is a diverse country with a vast range of ecosystems, socio-economic conditions, cultures and topography. The total area of the transboundary Indus river basin is 1.12 million km, ${ }^{2}$ distributed between Pakistan (47 per cent), India ( 39 per cent), China ( 8 per cent) and Afghanistan 6 per cent) (FAO 2012a). In Pakistan, the Indus river basin covers around 520,000 $\mathrm{km},{ }^{2}$ or 65 per cent, of the country, comprising the whole of the provinces of Punjab and Khyber Pakhtunkhwa (KPK), previously called the NorthWest Frontier Province (NWFP), and most of the territory of Sindh province and the eastern part of Baluchistan (FAO 2012b). The Indus river basin stretches from the Himalayan mountains in the north to the dry alluvial plains of Sindh province in the south and finally flows out into the Arabian Sea. The climate of the basin varies from subtropical arid and semi-arid to temperate sub-humid in the plains of Sindh and Punjab provinces to alpine in the mountainous highlands of the north. Annual precipitation ranges from $100 \mathrm{~mm}$ and $500 \mathrm{~mm}$ in the lowlands to a maximum of $2,000 \mathrm{~mm}$ in the mountains. Most of the precipitation is in winter and spring and originates from the west (Fowler and Archer 2006). Snowfall in the higher altitudes (above 2,500 m) accounts for most of the river run-off (Ojeh 2006). The upper Indus river basin is a high mountain region with glaciers and the mountains limit the intrusion of the monsoon.

Pakistan's is an agro-based economy, and the majority of the population depends upon agriculture for employment (Begum and Yasmeen 2011). In 2010-2011, 74.2 per cent of working women were concentrated in the agricultural sector. Most women agricultural workers were engaged in subsistence-level farming under harsh conditions and with hardly any economic security. Alongside is their unpaid work, including livestock management and vegetable farming (AGRA 2017; Government of Pakistan 2011). Climatic pressures are negatively impacting agricultural activities and increasing the vulnerabilities of women (Abubakar 2016; FAO 2015).

The Indus river basin can broadly be divided into three zones: upstream, mid-stream and downstream (ADB 2013). Women in these basins are responsible for household activities and are also engaged in crop production, 
livestock rearing and the cotton industry (Iftikhar et al. 2009; Kausar and Ahmad 2005).

The chapter is based on an anthropological study carried out along the Indus tributaries. It discusses women's vulnerabilities in the upper, middle and lower Indus basin, seeking to understand the differences in vulnerabilities across these three distinct geographies.

The chapter is divided into four sections. Section one reviews the literature on gender and climate-change issues with respect to the Indus river basin and tries to understand the differential vulnerabilities for women due to multiple stressors such as frequent disasters, floods and groundwater depletion in different geographical regions. Section two gives a short description of the study locations and methodology. Section three presents the perception of women across the three areas. Section four discusses these issues and concludes the chapter.

\section{Gender and climate change in the Indus basin}

Globally, women are major actors in dealing with climate shocks (IUCN 2007; UNDP 2009; UNFPA/WEDO 2009), and in particular in reducing vulnerabilities from these shocks. It is important to recognize how women in Pakistan, which ranks 12th for global vulnerability, are affected by climate change (Ahmed and Schmitz 2011: 2). There has been a noticeable increase in temperature of 0.6 degree Celsius over the last 100 years, and since 2000 a 0.08 degree Celsius increase in temperature per decade (Khan et al. 2016). The adverse effects of climatic changes are costing the economy almost US $\$ 5$ billion, about 5 per cent of GDP, annually and nearly 10 million people are being displaced by climate-induced disasters (Climate Emergency Institute 2017). Climatic variability impacts people living along the Indus river, which supports the world's biggest irrigation system, and is prone to severe flooding in July and August (World Bank 2011).

Emergent changes in temperature, precipitation, the incidence of extreme events, sea level and glacial cover are expected to impact water availability, adversely affecting agricultural production, nutrition, health and household incomes. Climate variability and water availability affect marginalized women engaged in farming and livestock rearing, increasing their vulnerabilities (Abbasi et al. 2018; Najam and Hussain 2015; Nizami and Ali 2017). In the rain-fed (barani) areas, men have moved away from agricultural production to diversify household incomes, and more women now manage the family farm than previously. By contrast, in the canal-irrigated areas in Sindh, where agriculture is more market oriented, cotton picking offers paid work opportunities for women. In Baluchistan and Gilgit Baltistan, where socio-cultural and patriarchal norms are more binding, agriculture is virtually the sole employer for rural women (Government of Pakistan 2013).

Climate change has severe effects on the health and wellbeing of a large number of women due to their role in both productive activities 
and reproduction. During the 2010 floods in Pakistan, the wellbeing of 713,000 women, including 133,000 pregnant women, was affected by lack of access to freshwater, diseases, snake bites and many other health problems (UNICEF 2010: 2). Gender-differentiated roles and responsibilities, rights, access, knowledge and priorities shape vulnerabilities, often causing women to suffer disproportionately during and after disasters because of socio-economic constraints and inequalities (Brody et al. 2008; Parikh 2007). Climate change is not gender neutral: in times of crisis women and men make different decisions, and their attitudes to risk, coping strategies, adaptability, and advice-taking and information-seeking behaviours also differ (Dankelman 2008). Consequently, vulnerability and the impacts of climate change will differ for different men and women according to the intersectionality of gender with other factors and stratifications, in this case, their location (Arora-Jonsson 2011).

Among the considerable number of work tasks undertaken by women are livestock rearing, collecting fodder, cleaning animals, making dung cakes, processing animal food products such as cheese, butter and yoghurt, and even marketing them (Hamid and Afzal 2013; Iftikhar et al. 2009). Additionally, they have household responsibilities such as childcare, water collection and cooking fuel collection (Begum and Yasmeen 2011; Butt et al. 2011; Kausar and Ahmad 2005). Nevertheless, there is a common perception that women, despite being the main major producers of food, are not allowed to become landowners (FAO 2015). Cultural barriers also limit women's access to resources. The scarcity of resources induced by climate shocks increases women's workload and time poverty, intensifying their vulnerabilities (Luqman et al. 2013; Rodenberg 2009: 26).

Migration is a major adaptation strategy for climate-induced vulnerabilities but due to resource constraints, it is often the most vulnerable, including women, who cannot migrate (Gioli et al. 2014; Mueller et al. 2014). When their husbands migrate for work, these women have to construct shelters, manage the household, and look after children and the elderly (Shah 2012). In short, they have to stay put and face the impacts of climate shocks.

However, climatic variability is not always disadvantageous for women (Abbasi et al. 2017). There are important gender implications not only to the decision to migrate but also to its consequences. Cultural norms and social structures restrict women's migration. Many migrants face unsafe working environments at their destinations, exacerbating their vulnerabilities. The increased role of women in agriculture enhances their food security. Moreover, attempts at capacity building for women, for instance in the Indus area of Gilgit and Baltistan, enhance their agency (Khan and Ali 2016).

\section{Study locations and methodology}

The main aim of this study was to explore women's vulnerabilities by understanding their perceptions of climate change and to highlight their 
resilience in the upper, middle and downstream areas of the Indus basin. Hyndman (2001) suggests that the link between geographical location and time can be understood as "the field is here and now, not there and then". The Hunza basin, which comprises the Hunza, Nagar and part of Gilgit districts, was selected to represent the upstream area. The focus group discussions (FGDs) were carried out in Minapin, Ali-Abad and Misigar villages. Key informants for interviews were selected from the FGDs. The Soan basin, comprising Attock, Chakwal, Islamabad, Khushab and Rawalpindi districts, were selected to represent the mid-stream. There are three different rainfall zones in the Soan basin due to topographical variations. Therefore, two FGDs were conducted in each zone. The villages of Upper-Numb Romal and Dhok Chawan were selected from the high rainfall zone of the mid-stream basin (Tehsil Murree, Rawalpindi district), while Saroja and Gang were selected from the medium rainfall zone (Chakri area). Similarly, from the low rainfall zone, Akwal and Ghool villages were selected for the FGDs (Talagang area). The Chaj Doab, comprising the Chiniot, Gujrat, Jhang, Mandibahuddin and Sargodha districts, was selected in the downstream basin. FGDs were conducted in Chak-7, Bhalwal and Sadha Kambo villages of the Sarghoda district (see Figure 5.1).

This study was conducted from June to October 2017 during the "participatory assessment of climate stress, drivers and conditions leading to different levels of vulnerability" fieldwork under the Himalayan Adaptation, Water and Resilience (HI-AWARE) project.

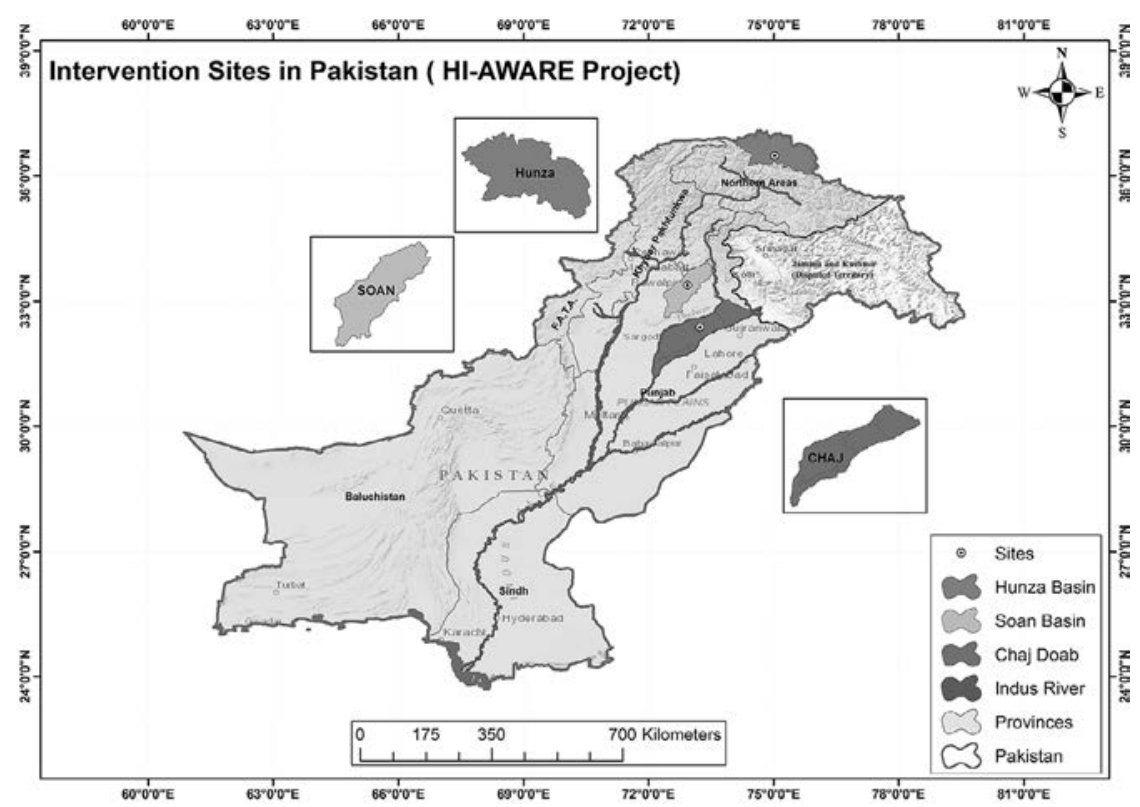

Figure 5.1 Hi-AWARE intervention sites in Pakistan.

Source: CAEWRI, NARC 2017. 
Twelve FGDs from the three basin levels were conducted, each group consisting of between seven and ten young, married, widowed and elderly women. The interviews mainly focused on climate change in the area, the impacts on local livelihoods, especially those of women, their vulnerabilities and their resilience mechanisms. The information generated was analyzed to determine women's vulnerabilities and common threats in the three basins. The study sought to determine the role of culture and geography in defining gender relations, and the linkages between the changing climate and vulnerabilities.

\section{Women's perception of climate change}

Perceptions of climate change are defined as people's awareness of its causes and adverse impacts (Leiserowitz 2006; Whitmarsh 2008). These perceptions enable people to make conscious livelihood choices to address the adverse effects (Ockwell, Whitmarsh and O'Neill 2009). Public understanding is an important factor in influencing policy decisions on climate-change issues (Leiserowitz 2006). The impacts of climate change on women are serious, as they are directly related to their livelihoods (Keith et al. 2014). Women have expert knowledge of climate-change impacts and priorities at local level because of the way climate change affects their work, roles and responsibilities (Morgan 2008; Perkins 2015). However, women continue to be missing from leadership positions addressing climate-related challenges (Baruah 2016; McFarland 2015), despite the important role they are starting to adopt in adaptation strategies (Dankelman 2010). The unpaid work of women makes a major contribution to developing and implementing climate-smart adaptation practices. These often make women even more invisible in public spheres, further marginalizing them in climate-change decision-making processes (Reed et al. 2014). There is a disproportionate burden on women's unpaid labour that further increases after extreme climatic events (McGregor 2012; Parikh and Denton 2003) (Table 5.1).

\section{Impact of climate change on women in the upstream basin}

The FGDs in the upstream basin sought to understand women's perceptions of climate change-related vulnerabilities and their local adaptation strategies. The majority of women noted an increased incidence of flooding, with 65 per cent reporting greater frequency of flash floods in recent years. A significant proportion of the households also reported that they observed erratic rainfall patterns, with an increased number of landslides in summer and a reduction in snowfall.

Women form a very significant proportion of the workforce in food production and have an important role in the sustainability of the mountain environment and its cultivation (FAO 2015). Due to the emigration of their menfolk, women have to deal with all day-to-day activities. In the upstream basin, agriculture has been the major source of livelihood for the people, 
Table 5.1 Socio-economic situation of women in Indus

\begin{tabular}{|c|c|c|c|c|c|c|c|c|}
\hline & Literacy Level & Mobility & Social Barriers & $\begin{array}{l}\text { Housebold } \\
\text { Work }\end{array}$ & Farm Work & Employment & Health & $\begin{array}{l}\text { Recreational } \\
\text { Activities }\end{array}$ \\
\hline Up-Stream & $\begin{array}{l}\text { High } \\
\text { (depending } \\
\text { upon } \\
\text { family } \\
\text { income } \\
\text { but overall } \\
\text { culture for } \\
\text { women } \\
\text { education } \\
\text { is very } \\
\text { positive) }\end{array}$ & $\begin{array}{l}\text { Easy, flexible } \\
\text { and more } \\
\text { comfortable }\end{array}$ & $\begin{array}{l}\text { Strict social } \\
\text { barriers } \\
\text { in case of } \\
\text { mixing } \\
\text { with other } \\
\text { communities } \\
\text { and sects but } \\
\text { somehow } \\
\text { relaxed in } \\
\text { terms of } \\
\text { decision } \\
\text { making }\end{array}$ & $\begin{array}{l}\text { Fully } \\
\quad \text { Responsible }\end{array}$ & $\begin{array}{l}\text { Equal } \\
\text { Participation } \\
\text { with men }\end{array}$ & $\begin{array}{c}\text { No Social or } \\
\text { Cultural } \\
\text { Barriers }\end{array}$ & $\begin{array}{l}\text { Basic health care } \\
\text { facilities are } \\
\text { available in the } \\
\text { area but for } \\
\text { complicated cases, } \\
\text { women have } \\
\text { to travel long } \\
\text { to reach Gilgit } \\
\text { City. Becomes } \\
\text { vulnerable } \\
\text { during extreme } \\
\text { climatic events } \\
\text { due to landslides } \\
\text { and travel } \\
\text { disconnections }\end{array}$ & $\begin{array}{l}\text { Available at } \\
\text { community } \\
\text { and } \\
\text { educational } \\
\text { institutions. } \\
\text { Higher } \\
\text { participation } \\
\text { rate no } \\
\text { family } \\
\text { restrictions }\end{array}$ \\
\hline Mid-Stream & $\begin{array}{l}\text { Medium (But } \\
\text { the trend } \\
\text { of women } \\
\text { education is } \\
\text { increasing } \\
\text { with } \\
\text { passage } \\
\text { of time as } \\
\text { compared } \\
\text { to past) }\end{array}$ & $\begin{array}{l}\text { Easy within the } \\
\text { village but } \\
\text { for outside } \\
\text { areas neither } \\
\text { flexible nor } \\
\text { comfortable } \\
\text { without } \\
\text { accompany of } \\
\text { male family } \\
\text { member }\end{array}$ & $\begin{array}{l}\text { Doesn't } \\
\text { have right } \\
\text { to make } \\
\text { decisions } \\
\text { or take } \\
\text { part in any } \\
\text { discussion }\end{array}$ & $\begin{array}{l}\text { Fully } \\
\quad \text { Responsible }\end{array}$ & $\begin{array}{l}\text { Participation } \\
\text { rate is high } \\
\text { but lower as } \\
\text { compared to } \\
\text { Up-Stream } \\
\text { Basin }\end{array}$ & $\begin{array}{l}\text { Allowed at } \\
\text { limited } \\
\text { scale and } \\
\text { professions } \\
\text { such as } \\
\text { teaching and } \\
\text { Health care }\end{array}$ & $\begin{array}{l}\text { Basic health care } \\
\text { facilities are } \\
\text { available in the } \\
\text { area but for } \\
\text { complicated cases, } \\
\text { women have } \\
\text { to travel long } \\
\text { distances, mostly } \\
\text { towards city area } \\
\text { of Rawalpindi and } \\
\text { Islamabad }\end{array}$ & $\begin{array}{l}\text { Available at } \\
\text { educational } \\
\text { institutions } \\
\text { and within } \\
\text { household } \\
\text { levels. } \\
\text { Mostly the } \\
\text { recreational } \\
\text { activities are } \\
\text { in shape of } \\
\text { festivals. } \\
\text { Participation } \\
\text { in sports } \\
\text { etc is not } \\
\text { encouraged }\end{array}$ \\
\hline
\end{tabular}




\begin{tabular}{|c|c|c|c|c|c|c|c|c|}
\hline $\begin{array}{l}\text { Down- } \\
\text { Stream }\end{array}$ & $\begin{array}{l}\text { Low (Still } \\
\text { on lower } \\
\text { side as } \\
\text { compared } \\
\text { to other } \\
\text { two basins } \\
\text { because of } \\
\text { social and } \\
\text { cultural } \\
\text { barriers) }\end{array}$ & $\begin{array}{l}\text { Only allowed } \\
\text { within } \\
\text { community } \\
\text { or village. } \\
\text { Women are } \\
\text { not allowed } \\
\text { to go out } \\
\text { without male } \\
\text { member. } \\
\text { Mobility is } \\
\text { strict }\end{array}$ & $\begin{array}{l}\text { No rights have } \\
\text { assigned } \\
\text { to women } \\
\text { she is not } \\
\text { allowed to } \\
\text { interfere in } \\
\text { any decision } \\
\text { taken } \\
\text { by male } \\
\text { member }\end{array}$ & $\begin{array}{l}\text { Fully } \\
\text { Responsible }\end{array}$ & $\begin{array}{l}\text { No participation } \\
\text { in crop and } \\
\text { livestock } \\
\text { activities. } \\
\text { Only poor } \\
\text { households } \\
\text { or tenants } \\
\text { women work } \\
\text { in farm }\end{array}$ & $\begin{array}{l}\text { Mostly strict } \\
\text { but teaching } \\
\text { is allowed in } \\
\text { near areas. }\end{array}$ & $\begin{array}{l}\text { Health care facilities } \\
\text { are available } \\
\text { at government } \\
\text { and private } \\
\text { level and also } \\
\text { at nearby areas. } \\
\text { Lack of facilities } \\
\text { at government } \\
\text { hospitals create } \\
\text { certain issues. }\end{array}$ & $\begin{array}{l}\text { Limited only } \\
\text { at household } \\
\text { level, during } \\
\text { marriages } \\
\text { and other } \\
\text { religious } \\
\text { festivals. }\end{array}$ \\
\hline
\end{tabular}

Source: SSRI and NARC survey data. 


\section{Saqib Shakeel Abbasi et al.}

with 70 per cent of the population dependent on it directly or indirectly. The emigration rate in Hunza district was the highest in Gilgit Baltistan, resulting in a labour shortage for agriculture (Gioli et al. 2014). From the FGDs it was observed that this trend is negatively impacting agricultural productivity. The main staple crop is wheat, but maize and barley are also cultivated. Cultivating fruit like apricots, peaches, pears, apples, grapes, cherries and melons, and vegetables such as potatoes, tomatoes and beans is an important source of income for local people. Women play a major role in the upstream basin, being solely responsible for value addition. Climatic changes, they said, have led to low agricultural production and farm incomes, particularly for their fruit crops. A substantial proportion of households reported a decline in the production of almost all horticultural crops.

The majority of the women from Gulmit village (upstream) mentioned in discussions that flash floods and landslides caused by climate change are becoming more common in the area and these occurred almost every year (see Figure 5.2). However, they also said that vulnerabilities affect women more than men because men are better equipped to act in a particular challenging situation than women. They added that men have better opportunities for mobility while women remain at home, further contributing to their level of vulnerability.

As well as hazards, households face food insecurity as their local livelihood sources are destroyed. Consequently, households' dependency on external food items supplied from downstream areas has increased. Furthermore, the food supply from other areas also gets interrupted due to infrastructure damage in the hazard-hit area. Vulnerabilities in the shape of food insecurity, poor infrastructure and physical isolation increase, and rehabilitation requires physical and financial resources.

The frequent flood events of the last decade have resulted in health issues for women, primarily due to poor sanitation. Women in the area had to sacrifice their own needs, including food, to meet their family's needs. Diseases, infections and injuries are more common in women during floods

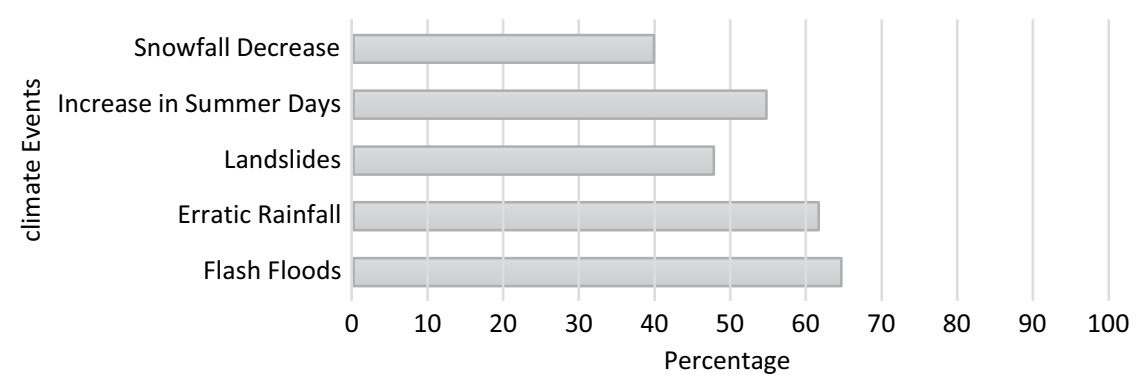

Figure 5.2 Women's perception: Climate induced events in UpStream Basin. Source: SSRI, NARC survey data, 2017. 
when they become homeless, or are living with relatives or in tents. Another important factor increasing climate-induced vulnerabilities for women in the upper Indus is the out-migration of men from the hazard-hit areas. With the men away, the women have to undertake men's tasks at home. Availability of clean drinking water after the floods is another major problem that upstream communities confront. Fetching water for domestic consumption is women's responsibility. They have to travel long distances in the harsh mountain areas. This is not only dangerous but also results in declining health, especially for pregnant and lactating women.

Women felt that in the upstream basin, climate change has led to significant degradation of open pastures and rangelands. Since sheep and the larger animals consume more fodder and water, as a coping strategy the women said they have reduced the number of their cattle and small ruminants. During environmental shocks such as floods, prolonged dry spells, drought or erratic rainfall, most farming households face food insecurity due to damage to their farming systems and other livelihood sources. The FGD participants mentioned that they had faced at least one shock in the preceding 12 months. The women mentioned that during these events households adopt various strategies to reduce the impact of shocks, such as replacing expensive food items with cheaper ones or borrowing from relatives. Most of them said they had reduced expenditure on clothing.

Some women mentioned that they changed their farming practices, growing short-duration crops to enhance their resilience to climate change. New crops, including seasonal vegetables, nuts and hybrid potatoes that withstand water stress and have a higher market value, are being grown with the help of NGOs. New farming practices include changing the sowing time and water conservation.

\section{Women's perception of climate change in the mid-stream basin}

The southern part of the mid-stream basin gets very hot in summer, while the northern parts experience very cold winters with heavy snowfall. January is usually the coldest and June the hottest month in the year. The area is at risk from erratic rainfall, hailstorms, droughts, heatwaves and cold waves. Crop cultivation and rearing livestock are becoming difficult for small farmers.

The FGDs showed that women were actively participating in agricultural activities and livestock rearing. Over the last three decades, women's living conditions have improved due to an increase in income, education and awareness through mass media. They are involved in important family decisions but still do not have the right to decide about marriage. Gender roles and responsibilities are fixed. Women are primarily responsible for domestic activities and men mainly perform outdoor activities. Women also contribute to farming activities ranging from land preparation to harvesting. In livestock management, women perform 70-80 per cent of the tasks. 


\section{Saqib Shakeel Abbasi et al.}

Women's health is affected by extreme heat during wheat harvesting. They reporting that collecting water from springs was a tough job and they often suffered from neck pain carrying water over long distances on their heads. Mothers expressed safety concerns about their daughters fetching water from a distance.

A woman from Saroba village pointed out during discussion that climate change-induced drought and heat stress is causing their agricultural land to become barren, increasing their poverty level. She mentioned that her husband is a daily labourer and during extreme weather his income is halved. She further added that male members can migrate but women do not tend to do so due to climate change, which increases their vulnerability level compared with their male counterparts. This woman also highlighted that due heat stress, women have more skin problems than men, as women left behind in the village are responsible for agriculture and livestock while the men migrated to the nearest city.

Rainfall variability further increases women's workload. Lack of rain causes seasonal scarcities in most parts of the mid-stream basin, increasing the burden on women who have to fetch water over long distances. Poor sanitation and hygiene practices resulting in water-borne diseases are found more commonly in women than men. Climatic variability in cropping patterns has also affected women. As men are responsible for buying seeds and sowing crops, their farming responsibilities end before those of the women. Women suffer more as they are engaged on farm work right up till harvesting, in addition to livestock and household management.

In the mid-stream basin livestock is a major source of livelihood and everyday routines are different from those in the upstream and downstream basins. In upstream areas, livestock is grazed on a collective community system. A few young men take the livestock of the entire community to the high-altitude pastures and live there for the whole summer. Individual households do not have to tend their animals daily in summer, and in winter, there is enough dry fodder for them. In downstream areas, livestock is kept in sheds in the farms and managed primarily by men. In the midstream areas, however, taking livestock to graze on nearby land is a daily practice.

\section{High rainfall zone (Tehsil Murree)}

Results from the FGDs indicate that in most households, the men are away from home, working in other cities, suggesting a larger burden of responsibility for women running the household, farmland and other village matters. Women are traditionally responsible for cooking, fetching drinking water, cleaning, feeding and milking livestock, sowing, weeding, harvesting, home gardening and so on. In Tehsil Murree, women were asked to recall the impact of climate change over a decade. They recalled that 10 years previously there had been green and fertile fields, where multiple crops including fruit and vegetables were grown. Livestock was kept by every family and water was easily available. But now everything has changed. The 


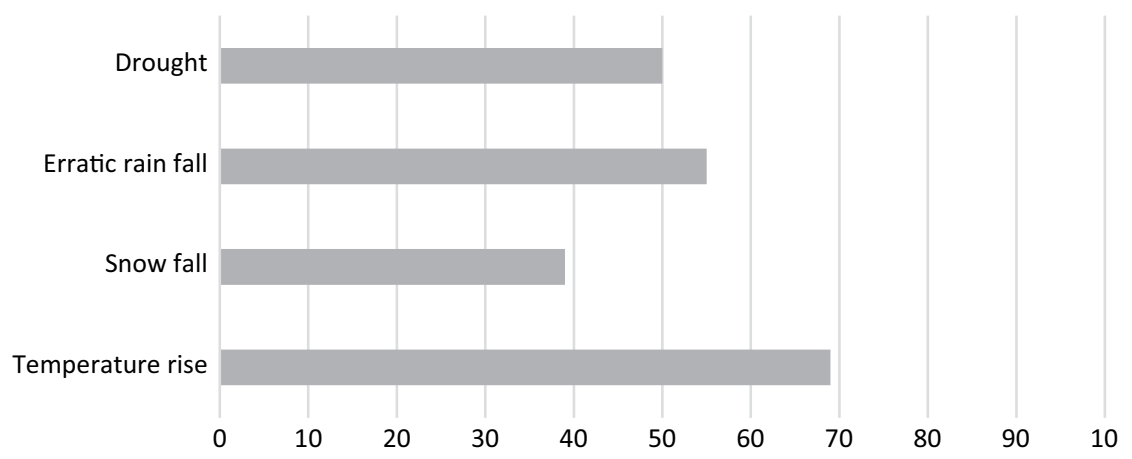

Figure 5.3 Women's perception: Climate-induced events in the High Rainfall Zone MIB (Pakistan).

Source: SSRI, NARC survey data, 2017.

orchards are barren and cereals are hardly cultivated. Few households still grow vegetables for their own consumption as well as a little for the market.

The women felt that winter snowfall had reduced, leading to livelihood vulnerabilities in the area. as crop yields were affected due to lower soil moisture. The majority of the women felt the temperature was rising. Erratic rainfall and drought were other climatic stressors reported. Women also mentioned snowfall as a climatic vulnerability. A number of health issues, including common cold, fever, throat infections and skin issues, were reported due to cold dry weather. These health issues are more common in women and children - in women due to more exposure to cold weather early in the morning, late nights and water-related activities (see Figure 5.3).

\section{Medium rainfall zone (Chakri)}

Women from Chakri and Sarooba villages, who rely on natural resources for their livelihood and food security, said that climate change is part of their everyday life. The women mentioned that droughts are affecting their socio-economic situation. They mentioned being susceptible to rising temperatures, erratic rainfall, droughts and fog (Figure 5.4). Uncertain rainfall made agriculture unreliable. Migration is seen as a major adaptation strategy to cope with climatic stressors.

\section{Low rainfall zone (Tehsil Talagang)}

The women in Ghool and Akwal villages spoke about extreme heat, changing weather patterns and how in the past they had been able to depend on the regular rains. Nowadays they said the rains were irregular and accompanied by high winds. The women talked about the early rains in summer and said that last year, heavy rains accompanied by high winds and hailstorms had 


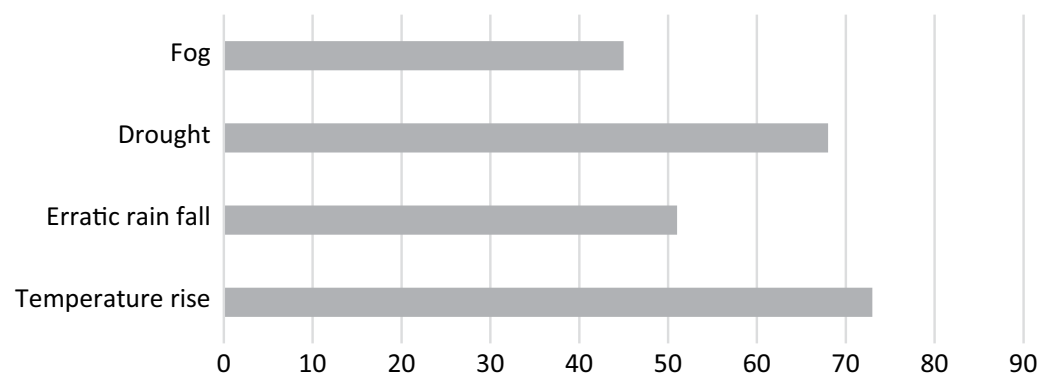

Figure 5.4 Women's perception: Climate-induced events in the Medium Rainfall Zone MIB (Pakistan).

Source: SSRI, NARC survey data, 2017.

damaged standing wheat and pulse crops. According to them, the intensity of both summer heat and winter cold had increased. These women perceive climate in terms of weather. To them climate meant winter, summer, heat, cold, rainfall, drought - the weather they experienced and lived with every day. Compared to a decade ago, seasonality and occurrences are changing, and the weather is unpredictable. A woman from Ghool village said, "Now the summers are longer and hotter. It is difficult to work in the intense heat. We have no electricity, and there is a severe water shortage. We feel sick, tired and uncomfortable, but we have to carry on with our daily domestic work." Other women added that the intense heat does not allow them to stay outdoors for long. Winters are colder than in the past. People begin work in the fields later in the day when it gets somewhat warmer. These adjustments to lifestyles and work schedules represent people's response to weather changes. In these two villages, the majority of women felt temperatures had risen and erratic rainfall patterns and droughts had increased in the last decade; they also identified fog as a new phenomenon (Figure 5.5).

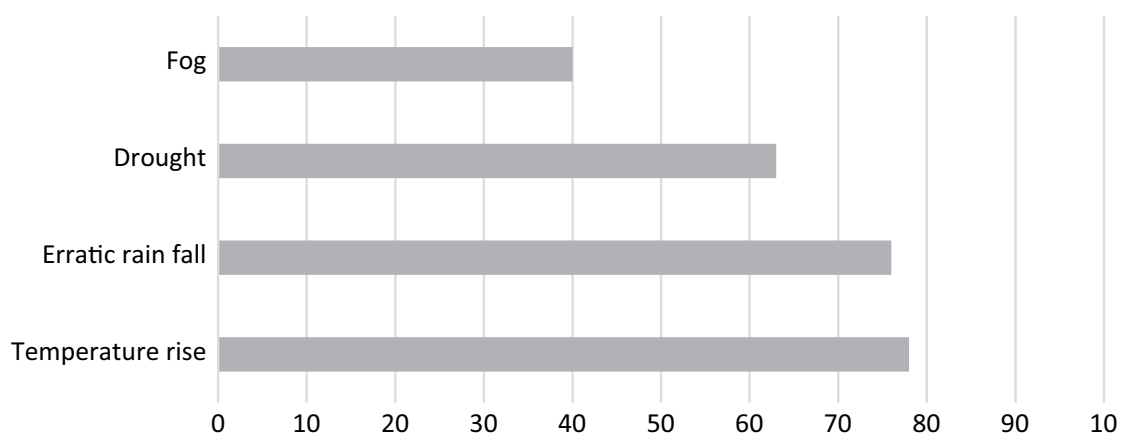

Figure 5.5 Women's perception: Climate-induced events in the Low Rainfall Zone MIB (Pakistan).

Source: SSRI, NARC survey data, 2017. 


\section{Women's perception of climate change in the downstream basin}

In the lower basin area, women's participation in agriculture was very limited, due to social norms that restrict them from working outside the home. Highly mechanized commercial agriculture further restricted women's participation (Figure 5.6). Large farms located some distance from the village do not create a suitable working environment for women. This is in contrast to the upstream and mid-stream areas, where subsistence farming in small plots located in the villages enable women to work in them. Sugar cane and wheat are the major crops and citrus fruits provide a major source of income.

Women here are not much exposed to farming and have limited interest in agriculture due to their higher level of education. Here both men and women emigrate for jobs or to seek higher education. Households with migrants have better-constructed houses and household assets, and better access to education and health facilities. However, the migration of men increases the workload of the women left behind. Overall, in around 10 per cent of families in the area, one or more men have migrated out of the village in search of better opportunities.

Women felt that over the last 10 to 20 years, the rains have become erratic, but annual precipitation has decreased. Rainfall is more intense but of shorter duration, followed by long dry spells. There is heavy fog in winter. Summers are longer, and winters are shorter. Changes in temperature and rainfall have also aggravated pest attacks on crops and livestock, threatening the livelihoods of the rural poor in the downstream area. A girl in village Chak-7 highlighted one very basic issue. She said that although climate change strikes both genders equally, when it comes to adaptation in the face of vulnerabilities women's freedom to follow their men is restricted because of their limitations in terms of mobility and access to resources. She stated that at times of climate-induced vulnerability such as flooding,

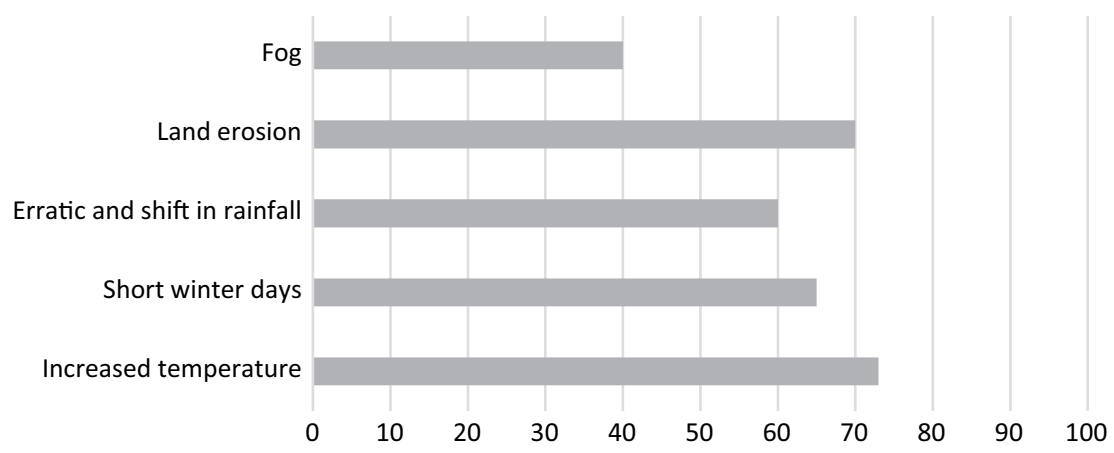

Figure 5.6 Women's perception: Climate-induced events in the Low Indus Basin LIB (Pakistan).

Source: SSRI, NARC survey data, 2017. 
women sacrificed their savings and even their jewellery. She added that girls are not allowed to keep mobile phones with them, but sometimes men have more than two phones.

Older women said that over time the condition of women has improved due to the increased incomes, improved education and education through mass media. Women were involved in important family decisions but had no say regarding marriages. In flood-prone areas of the basin, women said that some farmers have started cultivating sugar cane instead of rice as it is more resilient to floodwaters. Additionally, if their requirements cannot be fulfilled from canals, some farmers, especially citrus growers, are adopting improved irrigation techniques such as sprinklers and drip irrigation.

The FGDs revealed that though flooding was not common in the area, the floods of 1992 and 2010 caused a lot of damage. Changing patterns of rainfall, with heavy rains occurring just before the wheat harvests, the women said, caused most farmers to lose 100 per cent of their standing crop. Communities living in waterlogged areas are more vulnerable to crop losses. Most women said that during disasters they suffer the most due to limited access to financial, natural, institutional or social resources and also social norms like dress codes that hinder mobility. On the whole, the majority of women felt temperatures were rising, and had experienced land erosion, shorter winters, erratic rainfall and fog.

\section{Learning from women's vulnerabilities and responses to the changing climate}

This section draws on the vulnerabilities and capacities of women in the three basins of the Indus. (Table.5.2). It is apparent that climate change resulting in floods, changing rain cycles, river erosion, flood, heatwaves and cold impact human capital. It is, however, also clear that both women and men have the agency to meet the outcomes of climate shocks.

In the FGDs, the women explained that changing rain cycles, floods, soil and riverbank erosion and landslides, and heatwaves were the aspects of climate change that affect them the most. Major catastrophes deprive them of their lands, homes and livelihood assets. During these events, women undertake all the household tasks while men have to build shelters and provide food. However, women have to make the shelters liveable, and to cook, fetch water and arrange livestock fodder.

With harsh weather and difficult topography in the upstream basin, the daily life of men, women and children is precarious most of the time due to climate-induced hazards like glacial melts, glacial lake outburst floods (GLOF) and floods. Despite being custodians of culture, women are the most vulnerable in the mountains and must work harder than men to adapt.

In the mid-stream areas, women's drudgery is compounded by social barriers. They are not involved in major decisions and do not have land 
Table 5.2 Women's vulnerabilities to climate change in Indus basin

\begin{tabular}{|c|c|c|c|c|}
\hline Basin & Vulnerabilities & Threats and Stressors & Social and Cultural Norms & $\begin{array}{l}\text { Coping and } \\
\text { Adaptation Strategies }\end{array}$ \\
\hline Up-Stream & $\begin{array}{l}\text { - Harsh weather } \\
\text { - Difficult topography } \\
\text { - Climate induced hazards } \\
\text { - Lack of capacity building } \\
\text { - Lack of opportunities } \\
\text { - Small agricultural lands }\end{array}$ & $\begin{array}{l}\text { - Glacial melt } \\
\text { - GLOFS } \\
\text { - Floods } \\
\text { - Outmigration }\end{array}$ & $\begin{array}{l}\text { - Women are custodian of } \\
\text { household farming } \\
\text { - Women doesn't have land } \\
\text { ownership } \\
\text { - Women are not allowed to } \\
\text { participate in decision making }\end{array}$ & $\begin{array}{l}\text { - Out-migration } \\
\text { - Cropping pattern } \\
\text { changed according } \\
\text { to weather }\end{array}$ \\
\hline Mid-stream & $\begin{array}{l}\text { - Small landholdings } \\
\text { - Less resources } \\
\text { - Women health issues } \\
\text { - Gender biased society } \\
\text { - Climatic variability }\end{array}$ & $\begin{array}{l}\text { - Fog } \\
\text { - Drought } \\
\text { - Heat and cold waves } \\
\text { - Erratic/unpredictable } \\
\text { rainfall }\end{array}$ & $\begin{array}{l}\text { - Involved in agricultural and } \\
\text { livestock activities } \\
\text { - Responsible for household } \\
\text { activities/childcare }\end{array}$ & $\begin{array}{l}\text { - Out-migration } \\
\text { - Involved in } \\
\text { private and public } \\
\text { employment }\end{array}$ \\
\hline Down-stream & $\begin{array}{l}\text { - Degradation of natural } \\
\text { resources } \\
\text { - Less availability of } \\
\text { resources for everyday life } \\
\text { - Water logging \& salinity } \\
\text { - Social norms }\end{array}$ & $\begin{array}{l}\text { - Climatic variabilities } \\
\text { - Heavy Fog } \\
\text { - Erratic rainfall } \\
\text { - Droughts }\end{array}$ & $\begin{array}{l}\text { - Women restricted to home } \\
\text { - Women are excluded from } \\
\text { education } \\
\text { - Women are excluded from } \\
\text { employment } \\
\text { - Women are not allowed to } \\
\text { move out without family head }\end{array}$ & $\begin{array}{l}\text { - Out- migration } \\
\text { - Education/awareness } \\
\text { programs for local } \\
\text { women }\end{array}$ \\
\hline
\end{tabular}

Source: SSRI, NARC survey data. 
ownership rights. Though the Islamic Shariah law define men's and women's shares in property, in practice these stipulations are ignored or waived (Ahmad 2010; SDPI 2011). Women generally have limited resources for subsistence. However, they are equally responsible for the care of livestock.

Rural customs and urban norms reinforce gender inequality in the midstream basin. Women are far behind men here. One of the reasons for this is their low representation in governance. On the other hand, climate change is adversely impacting agriculture, water and food security severely, affecting their health. Over the last decade, temperature and precipitation patterns have significantly changed, increasing the vulnerability of women and children.

In the downstream villages, due to commercialization and mechanization of agriculture, women are kept away from agriculture and are responsible for household chores. Social barriers and norms do not allow women to go out without male family members in contrast to the upstream areas where women have freedom of movement. In the mid-stream areas, there are no restrictions on women accessing education, but they are not encouraged to move out of the city and or to find work.

Climate, and in particular rising temperatures, is negatively impacting agriculture, exacerbating the existing socio-economic stresses of the many factors impacting livelihoods, such as lack of medical facilities for both humans and livestock, and the unavailability of pesticides. Furthermore, lower-income groups who lack savings are forced to borrow from informal credit sources at high rates of interest. Sometimes they have to sell their livestock, or in extreme cases, to sell some land for less than its true value.

In terms of adaptation practices against vulnerabilities, women have to follow their men due to financial and social constraints. Men dominate the labour markets; women's agricultural work is mostly unpaid. An emerging phenomenon is the presence in the labour market of women from poorer households. This has improved their lives and the adaptation capacities of their households. But social barriers restrict mobility for the majority of the women. Saving money is the most significant adaptation strategy for women in the mid- and lower basins; almost all the women strongly agreed that this enabled them to meet contingencies like weddings, deaths, children's education and floods. While these savings are not sufficient to meet all costs in crisis situations, they are enough to meet the most important ones. In most countries of South Asia, women save money for emergencies either through cooperatives or individually, hiding it from the men who might spend it. The other important common adaptation strategy for women is rearing small ruminants that can be sold when needed. Women are responsible for fodder for livestock and poultry. They said they save dry fodder against disasters and in advance of the rains.

Women in the mid-basin have access to health facilities. Those in the higher and lower basins do not, so they use home remedies. During heat stress, women adapt by avoiding unnecessary outdoor activities and using traditional drinks. 
Due to the increasing migration of their men, women manage the household, farm and livestock. At times of extreme climate events and disasters, their workload greatly increases, often at the cost of their health. Nevertheless, women are rapidly adapting to climate change thanks to the local NGOs. New houses and animal sheds are being constructed in safer places; crop rotations and climate-smart agricultural practices have been introduced in the area. Women are learning new skills for value addition to crops to enhance their incomes, and buying smaller livestock to save scarce water resources. They are increasing their savings in local cooperatives.

This chapter has highlighted how climate change has enhanced both the vulnerability and the agency of women. Although women in Pakistan have the right to land by law, they rarely own it, and in some downstream areas culture prevents women from participating in agricultural activities. Although overall, women's link to agriculture is strong, as it provides food security, this relationship remains location specific. Upstream, about 70 per cent of women work in agriculture due to a shortage of labour. Downstream, women do not work in agriculture as it is being mechanized so the work is moving beyond their reach. Some women in mid-stream areas are educated and choose not to work in agriculture, opting instead to cultivate fruit and vegetables, which are relatively more resilient to water stress and command a higher market value. In some places sugar cane, a cash crop, has replaced rice as it is more resilient to floodwaters. In the canal region, as water decreases there is a change to sprinklers and drip irrigation.

Climate variability contributes to the vulnerability of women when there is snowfall, fog or heat. Research shows that this is a major problem impacting the vulnerability of women, who are finding it difficult to work outside for longer with summers getting longer. For instance, women in Murree are affected by the heat. According to the research, "Women differ from men in their physiologic compensation to elevated temperatures, which contributes to their biologic vulnerability"; other factors include "access to healthcare and cooling facilities due to personal safety concerns and a lack of access to personal transportation, culturally prescribed heavy clothing garments that limit evaporative cooling, and a lack of awareness of women's vulnerabilities to heat" (Sorenson et al. 2018: 284). Women may need to learn further to adapt to heat and climate change; one suggestion is to train them to protect themselves from heat waves (Abubakar 2016). The distinct geographies and multiple stressors highlighted in this chapter, such as water, disasters, snowfall and heat, play a role in a cultural shift that is seeing women step out of their earlier roles and adapt to the vulnerabilities inflicted by climate change.

Women do not remain without agency; they adapt to change when there is a need. Overall, this study shows that women are adaptive and are capable of coping with the adverse impacts of climate change, despite severe social and cultural constraints on their mobility and decision making on issues such as marriage. Women can therefore play an important role in building resilience if their voices are raised and heard. It is clear that there 


\section{Saqib Shakeel Abbasi et al.}

is an urgent need to involve women in change-making climate adaptation strategies and policies. Capacity building through training on disaster risk reduction (DRR), and climate-smart interventions such as rainwater harvesting and tunnel farming would increase resilience. Adaptation is the key to removing vulnerability and increasing resilience, and this study has shown women's ability to adapt in various sectors. Access to, and control and ownership by women of the resources of land, livestock, property and income opportunities must be recognized by policymakers and wider society if this process is to be further enhanced.

\section{References}

Abbasi, S., Muhammad, A., Nusrat, H., Kaiser, K. and Kanwal W. 2018. 'Identifying Gender Vulnerabilities in Context of Climate Change in Indus Basin', Environmental Development, 1: 34-42.

Abbasi, S.S., Ahmad, B., Ali, M., Anwar, M.Z., Dahri, Z.H., Habib, N., Hussain, A., Iqbal, B., Ishaq, S., Mustafa, N., Naz, R., Virk, Z.T. and Wester, P. 2017. 'The Indus Basin: A Glacier-fed Lifeline for Pakistan'. HI-AWARE Working Paper 11. Kathmandu: HI-AWARE.

Abubakar, S.M. 2016. 'Women and Climate Change'. The International News. https://www.thenews.com.pk/print/116402-Women-and-climate-change. Accessed on 28 September 2019.

ADB. 2013. 'Indus Basin Floods: Mechanisms, Impacts, and Management Mandaluyong City, Philippines'. Mandaluyong: Asian Development Bank.

AGRA. 2017. 'Africa Agriculture Status Report: The Business of Smallholder Agriculture in Sub-Saharan Africa.' Nairobi: Alliance for a Green Revolution in Africa (AGRA), Issue No. 5.

Ahmad, N. 2010. 'Land Rights for Pakistani (Muslim) Women: Law and Policy 1.' Policy Brief Series No. 23. SDPI Islamabad. https://sdpi.org/publications/ files/Microsoft $\% 20$ Word $\% 20-\% 20$ policy $\% 20$ Brief $\% 2023$.pdf. Accessed on 1 December 2019.

Ahmed, N.M. and Schmitz, M. 2011. 'Economic Assessment of the Impact of Climate Change on the Agriculture of Pakistan', Business and Economic Horizons, 1-12.

Arora-Jonsson, S. 2011. 'Virtue and Vulnerability: Discourses on Women, Gender and Climate Change', Global Environmental Change, 21: 744-751.

Baruah, B. 2016. 'Renewable Inequity? Women's Employment in Clean Energy in Industrialized, Emerging Developing Economies', Natural Resources Forum. A United Nations Journal, 41(1): 18-29.

Begum, R. and Yasmeen, G. 2011. 'Contribution of Pakistani Women in Agriculture: Productivity and Constraints', Sarhad Journal of Agriculture, 27(4): 637-643.

Brody, A., Justin, D. and Emily, E. 2008. 'Gender and Climate Change: Mapping the Linkages. A Scoping Study on Knowledge and Gaps.' BRIDGE, Institute of Development Studies (IDS), UK.

Butt, T.M., Hassan, Y.Z., Mehmood, K. and Muhammad, S. 2011. 'Role of Rural Women in Agricultural Development and their constraints', Journal of Agricultural Science, 6(3): 53-56.

Climate Emergency Institute. 2017. 'Global Warming and its Impacts on Pakistan.' Retrieved from https://www.climateemergencyinstitute.com/uploads/global_ warming_and_its_impacts_o n_Pakistan.pdf. Accessed on 4 August 2019. 
Dankelman, I. 2008. 'The Issues at Stake: Gender, Climate Change and Human Security.' Women's Environment and Development Organisation, cited in Women's Health Victoria, 10-Point Plan for Victorian Women's Health 20102014, 2010.

Dankelman, I. 2010. Gender and Climate Change: An Introduction. Routledge.

FAO. 2012a. 'Irrigation in Southern and Eastern Asia in figures.' AQUASTAT Survey 2011. Rome: FAO, 129-140.

FAO. 2012b. AQUASTAT Database, Dataset for Country Water Resources Utilized. Retrieved from http://www.fao.org/nr/water/aquastat/main/index.stm. Accessed on 21 September 2019.

FAO. 2015. 'Women in Agriculture in Pakistan.' Retrieved from http://www.fao. org/3/a-i4330e.pdfFSAf. Accessed on 9 October 2019.

Fowler, H.J. and Archer, D.R. 2006. 'Conflicting signals of climate change in the Upper Indus basin', Journal of Climate, 19: 4276-4293.

Gioli, G., Khan, T., Scheffran, J., Aneel S, Haroon, U.T., Niazi, I. 2014. 'Gender and Environmentally-induced Migration in Gilgit-Baltistan, Pakistan.' In, Sustainable Development in South Asia: Shaping the Future. Islamabad: Sustainable Development Policy Institute and Sang-e-Meel Publishers, 355-378.

Government of Pakistan. 2011. Labour Force Survey 2010-11 (4th Quarter). Islamabad: Statistics Division, Pakistan Bureau of Statistics.

Government of Pakistan. 2013. Labour Force Survey 2012-13. Islamabad: Statistics Division, Pakistan Bureau of Statistics.

Hamid, A.J. and Afzal, J. 2013. 'Gender, Water and Climate Change: The Case of Pakistan.' Pakistan Water Partnership Policy Paper Series.

Hyndman, J. 2001. Geographical Review. 19(1/2): 262-272.

Iftikhar, N., Ali, T., Ahmed, M., Maan, A.A. and Haq, Q. 2009. 'Training Needs of Rural Women in Agriculture: A Case Study of District Bhawalpur.' Pakistan Journal of Agricultural Science 46 (3): 200-208.

IUCN. 2007. Gender and Climate Change: Women as Agents of Change. Retrieved from http://cmsdata.iucn.org/downloads/climate_change_gender.pdf. Accessed on 11 December 2019.

Kausar, T. and Ahmad, S. 2005. 'Social Stratification in the Participation of Women in Agricultural Activity: A Case Study of District Khushab Punjab, Pakistan', Pakistan Geographical Review, 60(2): 80-86.

Keith, P., Sibonokuhle, N. and Tanyaradzwa, B.C. 2014. Climate Change Impacts on Rural Based Women: Emerging Evidence on Coping and Adaptation Strategies in Tsholotsho, MCSER Publishing, Rome-Italy. Mediterranean Journal of Social Sciences, 5(23): 2545. doi:10.5901/mjss.2014.v5n23p2545

Khan, A.M., Khan, A.J., Ali, Z., Ahmad, I. and Ahmad, N.M. 2016. 'The Challenge of Climate Change and Policy Response in Pakistan', Environment Earth Science, 27: 412.

Khan, M. and Ali, Q. 2016. 'Socio-Economic Empowerment of Women in Pakistan; Evidences from Gilgit-Baltistan', International Journal of Asian Social Science, Asian Economic and Social Society, 6(8): 462-471.

Leiserowitz, A. 2006. 'Climate Change Risk Perception and Policy Preferences: The Role of Affect, Imagery, and Values', Climatic Change, 77(1-2), 45-72. doi:10.1007/s10584-006-9059-9.

Luqman, M., Shahbaz, B., Khan, I.A. and Safdar, U. 2013. 'Training Needs Assessment of Rural Women in Livestock Management: Case of Southern Pujab, Pakistan', Journal of Agriculture Research, 51(1): 99-108. 


\section{Saqib Shakeel Abbasi et al.}

McFarland, J. 2015. 'Are there jobs for women in green job creation?' Women \& Environments, 89/90, fall 2014/winter 2015. Retrieved from www.weimagazine. com.

McGregor, D. 2012. 'Traditional Knowledge. Considerations for Protecting Water in Ontario', International Indigenous Policy Journal, 3(3), Art. 11. Retrieved from https://ir.lib.uwo.ca/iipj/vol3/iss3/11.

Morgan, C. 2008. 'The Arctic: Gender issues', Parliamentary Information and Research Service Publication PRB, 08-09E.

Mueller, V., Gray, C. and Kosec, C.. 2014. 'Heat stress increases long term migration in rural Pakistan', National Climate Change, 4(3): 182-185.

Najam, N. and Hussain, S. 2015. 'Gender and Mental Health in Gilgit-Baltistan, Pakistan', Journal of Pioneering Medical Sciences, 5: 117-120.

Nizami, A. and Ali, J.. 2017. 'Climate Change and Women's Place-based Vulnerabilities - a Case Study from Pakistani Highlands', Climate and Development, 9(7): 662670. doi:10.1080/17565529.2017.1318742.

Ockwell, D., Whitmarsh, L. and O’Neill, S. 2009. 'Reorienting Climate Change Communication for Effective Mitigation Forcing People to be Green or Fostering Grass-Roots Engagement?', Science Communication, 30(3): 305-327. $10.1177 / 1075547008328969$.

Ojeh, E. 2006. Hydrology of the Indus Basin. Retrieved from https://webspaceutexas.edu/eno75/HYDROLOGY\%20OF\%20THE\%20INDUS\%20BASIN\%20 by\%20Elizabeth\%20Ojeh.doc. Accessed on 10 February 2019.

Parikh, J. 2007. 'Gender and Climate Change: Framework for Analysis, Policy and Action. Report by UNDP India.' Retrieved fromwww.data.undp.org.in/Gender_ CC.pdf. Accessed on 18 June 2019.

Parikh, J. and Denton, F. 2003. 'Gender and Climate Change', at COP8: A forgotten element.

PBS. 2019. Paksitan Bureau of Statistics. Retrieved from http://www.pbs.gov.pk/ sites/default/files/population_census/Administrative\%20Units.pdf. Accessed on 12 June 2019.

Perkins, P.E. 2015. 'Gender and Climate Justice in Canada', Women and Environments. International Magazine. (Special Issue: Women and Work in Warming World), 94/95, fall 2014/Winter 2015, 17-20.

Reed, M.G., Scott, A., Natcher, D. and Johnson, M. 2014. 'Linking Gender, Climate Change, Adaptive Capacity, and Forest-Based Communities in Canada', Canadian Journal of Forest Research, 44(9), 995-1004.

Rodenberg, B. 2009. 'Climate Change Adaptation from a Gender Perspective'. Bonn: German Development Institute.

SDPI. 2011. Women and Land. In-focus case study. Islamabad IDRC. CRDI. https:// www.idrc.ca/sites/default/files/sp/Documents \% 20EN/Pakistan-in-focus-casestudy-women.pdf. Accessed on 24 December 2019.

Shah, A.S. 2012. 'Gender and building homes in disaster in Sindh, Pakistan', Gender \& Development, 20(2): 249-264.

Sorenson, C.S., Saunik, M., Sehgal, A., Tewari, M., Govindan, J.L. and J. Balbus. 2018. 'Climate Change and Women's Health: Impacts and Opportunities in India.' Advancing Earth and Space Science. https://doi.org/10.1029/2018GH000163. Accessed on 21 February 2019.

UNDP. 2009. 'Resource Guide on Gender and Climate Change.' Retrieved from http://content.undp.org/go/cmsservice/download/asset/?asset_id $=1854911$. Accessed on 24 September 2019. 
UNFPA/WEDO. 2009. Climate Change Connections. Gender and Population. Retrieved from http://www.wedo.org/category/act/climate-change-toolkit. Accessed on 27 September 2019.

UNICEF. 2010. 'Pakistan Monsoon Floods Immediate Needs for Women and Children affected by Monsoon Floods', 5 August 2010, Pakistan. https://www. unicef.org/french/infobycountry/files/UNICE_Immediate_Needs_Document_ for_Pakistan_5_August_2010.pdf. Accessed on 25 December 2019.

Whitmarsh, L. 2008. 'What's in a name? Commonalities and differences in public understanding of "climate change" and "global warming", Public Understanding of Science, 18(4): 401-420. doi:10.1177/0963662506073088 (21 October 2019).

World Bank. 2011. Vulnerability, Risk Reduction and Adaptation to Climate Change. Washington, DC: Climate Risk and Country Profile Pakistan. 